\title{
Type of wood and larval density: two factors to consider in Dermestes
} maculatus (Coleoptera: Dermestidae) pupation

\author{
ZANETTI, Noelia I. ${ }^{1, *}$, FERRERO, Adriana A. ${ }^{1} \&$ CENTENO, Néstor D. ${ }^{2}$ \\ ${ }^{1}$ Laboratorio de Zoología de Invertebrados II, Departamento de Biología, Bioquímica y Farmacia, Instituto \\ de Ciencias Biológicas y Biomédicas del Sur (CONICET-UNS). Bahía Blanca, Argentina. \\ *E-mail: noeinesz@yahoo.com.ar \\ ${ }^{2}$ Laboratorio de Entomología Aplicada y Forense, Departamento de Ciencia y Técnica, Universidad \\ Nacional de Quilmes. Quilmes, Argentina.
}

Received 14 - II - 2020| Accepted 08 - V - 2020| Published 29 - VI - 2020

https://doi.org/10.25085/rsea.790205

\section{Tipo de madera y densidad larval: dos factores a considerar en la pupación de Dermestes maculatus (Coleoptera: Dermestidae)}

RESUMEN. Dermestes maculatus DeGeer (Coleoptera: Dermestidae) es uno de los escarabajos más comunes en las granjas aviares e instalaciones ganaderas. Los adultos y larvas dañan estas instalaciones al alimentarse y al momento de pupar. Esta especie también ha sido reconocida como un componente significativo de la fauna cadavérica. Ensayos fueron conducidos para estudiar el efecto del tipo de sustrato, particularmente el tipo de madera, y la densidad larval sobre la pupación de $D$. maculatus. Las pupas fueron más abundantes en madera blanda que en los otros tipos de madera, disminuyendo su abundancia con el incremento de la densidad. La mortalidad larval fue mayor en presencia de 60 larvas. El tiempo hasta la pupación fue menor en madera blanda que en los otros tipos de madera, pero se observó un incremento en dicha duración cuando aumentó la densidad. La duración promedio como pupa fue 7,25 $\pm 0,28$ días ( $174 \pm 6,72 \mathrm{~h}$ ). El tiempo hasta adulto mostró los mismos resultados que aquellos obtenidos para el tiempo hasta pupar. La longitud de los adultos fue mayor en madera blanda que en los otras maderas, pero decreció cuando aumentó la densidad. La madera blanda y la densidad larval tienen efectos en la pupación de los derméstidos, afectando la preferencia de las larvas por las maderas, la mortalidad larval, el tiempo hasta pupa, el tiempo hasta adulto, y la morfología del adulto. Se proveen recomendaciones para los granjeros o criadores de animales y cientíicos, como así también información de importancia forense en la estimación del intervalo post-mortem (IPM).

PALABRAS CLAVE. Entomología forense. Insectos plaga. IPM. Pupa. Tamaño poblacional.

ABSTRACT. Dermestes maculatus DeGeer (Coleoptera: Dermestidae) is one of the most common beetles in poultry farms and livestock facilities. Adults and larvae damage these facilities through feeding and at the moment of pupation. This species has also been recognized as a significant component of the cadaveric fauna. Trials were conducted to study the effect of substrate type, particularly of the wood type, and larval density on $D$. maculatus pupation. Pupae were more abundant in soft wood than in the other types of wood, decreasing abundance when density increased. Larval mortality was greater in the presence of 60 larvae. Time until pupation was lesser in soft wood than in the other woods but an increasing duration was observed when density increased. Pupa average duration was $7.25 \pm 0.28$ days ( $174 \pm$ $6.72 \mathrm{~h}$ ). Time until adult showed the same results that those obtained for the time until pupation. The adult length was greater in soft wood than in the other woods but it decreased when density increased. Soft wood and larval density have effects on hide beetles pupation, 
Revista de la Sociedad Entomológica Argentina 79(2): 35-42, 2020

affecting larvae preference for woods, larval mortality, time until pupation, time until adult, and adult morphology. Recommendations to farmers or animal breeders and scientists were provided as well as data of forensic importance in the post-mortem interval (PMI) estimation.

KEYWORDS. Forensic entomology. Insect pest. PMI. Population size. Pupa.

\section{INTRODUCTION}

The genus Dermestes is a commercial and household pest. These beetles are common in places that contain an appropriate food source or pupation site such as homes, museums, livestock facilities, etc. (Florent et al., 2015). The interest for rearing dermestids under laboratory-controlled conditions and in particular for rearing hide beetles, Dermestes maculatus DeGeer (Coleoptera: Dermestidae), arose from the damage that these insects cause to stored animal products and foods for human consumption (Osuji, 1975; Samish et al., 1992; Rajendran \& Parveen, 2005) around the world. These animal products are also prone to insect pest at the processing stage. Museum collections, historical materials, and dead insects in attics of houses, are another potential food source for dermestids (Su \& Scheffrahn, 1990; Florent et al., 2015). In addition, hide beetles are an important pest of non-edible animal products including silkworm cocoons, and silk production (Veer et al., 1996; Rajendran \& Parveen, 2005). Other Dermestes species also damage cloth made out of cotton, linen and synthetic fibers while they feed on their natural foods (Bennet et al., 1988). Furthermore, hide beetles are among the most common beetles in poultry farms (Turner Jr., 1986; Geden \& Carlson, 2001; Geden \& Steinkraus, 2003) and they have even been reported to feed on live turkeys (Samish et al., 1992). Mainquist et al. (2015) found that $D$. maculatus infests and causes significant structural damage to swine barns. The damage is the result of adults and larvae feeding as well as larvae pupation (Clark, 1929; Hinton, 1945; Kritzinger, 1955; Shuttleworth \& Galloway, 1961; Cloud \& Collison, 1985). The latter larval stage causes damage by tunneling into wooden structures and various other construction materials (Levinson et al., 1967; Jefferies, 1979; Wildey \& Wayman, 1979; Cloud \& Collison, 1986; Stafford et al., 1988). All this entails an economical importance.

Dermestes maculatus has also been recognized as a significant component of the insect fauna associated with decomposing remains, both human and animal, and so of forensic entomology and forensic taphonomy (Goff, 1993; Oliva, 2001; Schroeder et al., 2002; Zanetti et al., 2014, 2015). Hide beetles may also be used to clean bones to assist with forensic cases and taxidermy in museums due to their ability to clear skin and hair off bodies cleanly (Hefti et al., 1980; Mairs et al., 2004). Moreover, hide beetles are vectors of pebrine and due to their feeding habits, they can disseminate anthrax (Hinton, 1945). Occasionally, these beetles may also cause urticarial and allergic reactions, including rhinitis and asthma (Rustin \& Munro, 1984).

The aims of this work were to study the effect of different substrates, particularly wood types, and larval densities on $D$. maculatus pupation under controlledlaboratory conditions, to increase the knowledge on the biology of these beetles, to prevent wood damage, and to supply data of forensic importance in the estimation of the post-mortem interval (PMI).

\section{MATERIAL AND METHODS}

\section{Establishment of a colony}

New cultures of hide beetles were started in 2017 by collecting adults of this species during autumn and winter from cow carcasses that were located in Colonia San Adolfo fields (-39.4333 S, -62.55 W), province of Buenos Aires, Argentina. The cultures were maintained at $22 \pm 3{ }^{\circ} \mathrm{C}, 44 \pm 2 \% \mathrm{RH}$, and a photoperiod of $12: 12$ $h(L: D)$ in an incubator (Obsar, Córdoba, Argentina). Three centimeters of cat litter, pieces of soft wood and a piece of cotton were placed as substrates inside a plastic container to provide refuge and sites for pupation for beetles (Zanetti et al., 2016). The piece of cotton was soaked with distilled water as a water source. Insects were fed with pork meat and dog food.

\section{Rearing $D$. maculatus with different types of woods and larval densities}

Larvae of fifth and sixth instar were collected and distributed among three plastic containers of $10 \mathrm{~cm}$ length $\times 8 \mathrm{~cm}$ in diameter. Each treatment was established by $8 \mathrm{~cm}$ long and $1.5 \mathrm{~cm}$ width piece of soft wood (T1) (Populus alba L.), semi-hard wood (T2) (seasoned P. alba), or hard wood (T3) (Acacia caven Molina). Larval density (10, 30 or 60 larvae) was also evaluated in each treatment. For the same reasons explained above, $3 \mathrm{~cm}$ of cat litter and cotton pieces were added to the containers. The insects were fed with $10 \pm 1 \mathrm{gr}$ pork meat weighted with a scale (Ohaus Pioneer, Parsippany, NJ, USA). The graphic of the design is shown in figure 1a. The containers were introduced in an incubator (Ingelab, Almirante Brown, Buenos Aires province, Argentina) at $30 \pm 0.1^{\circ} \mathrm{C}, 44 \pm$ $2 \%$ relative humidity and $12 / 12 \mathrm{~h}$ light/dark photoperiod. The containers were inspected every two-three days until insects reached the adult stage, to assess 

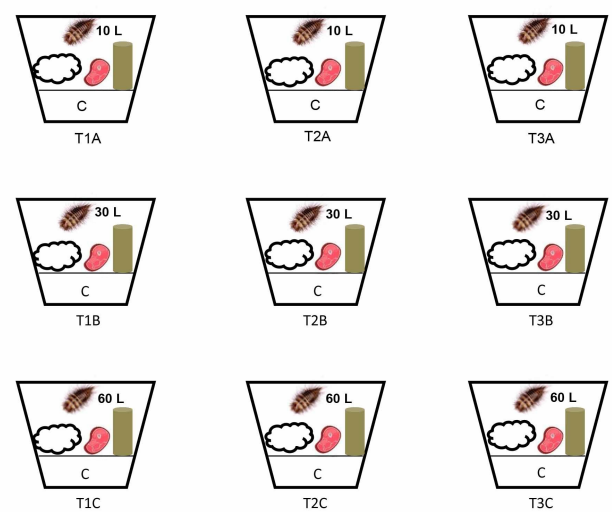

C: cat litter; 1 : cotton;
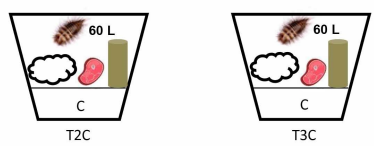

: larvae of D. maculatus

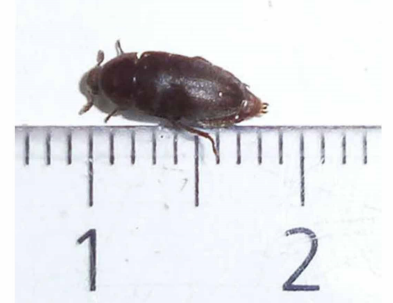

Fig. 1. a. A graphic of the experimental design. b. Length of Dermestes maculatus adult. T1: soft wood; T2: semi-hard wood; T3: hard wood. 10 L: 10 larvae; 30 L: 30 larvae; 60 L: 60 larvae. A, B, and C: replicates.

pupation, adult emergence, and mortality of larvae and pupae. Sex ratio and length of adults were also evaluated. This latest parameter was measured from the head to the rearmost abdominal segment with a rule (Fig. 1b).

\section{Statistical analyses}

Two replicates of the trials were made, each one with three replicates per treatment. For the percentage of pupae in wood (due to the results obtained) the responses to larval densities were only compared with T1. On the other side, they were compared with the larval and pupal mortalities according to larval density (substrate was not considered as a variation factor). The percentage of adult sexes was also calculated according to larval density and without considering substrate as a variable; females were arbitrary considered as "success". Pupae proportion in wood, dead larvae and dead pupae proportions, and proportion of female adults were based on variables with a binomial distribution. Besides, these distributions had a different " $n$ " parameter depending strongly on the density factor. For this reason, a generalized lineal model (GLM) was applied using as linking function the "Logit". Due to different observations, the model could underestimate the variance, so a scale parameter to

widen the binomial variance (quasi-binomial) (McCullagh \& Nelder, 1999) was added. The Wald test was used in its "F" version to compare densities. A chi square test was used in order to know if the sex ratio was equal to 1 .

Individuals were the experimental unit for the following variables, time until pupation, pupa duration, time until adult and adult length. Each experimental unit media, as long as it was based on more than two individuals, was used. For the time until pupation, only in T1, wood versus the other alternative substrates (cat litter, cotton or pork) was first compared using a T-test of pairing medias. Then, differences between wood substrates and larval densities were evaluated with a two-way ANOVA. This was also applied for the analysis of the time until adult (from latest larval stages to adult), the pupa duration (calculated in each experimental unit, as long as both values were based on more than two observations each, as time until adult medias minus time until pupation), and the adult length. Pair comparisons between wood substrates and larval densities were performed with LSD. Marginal media were used when no interaction existed. InfoStat $2012 \mathrm{p}$ version (FCAUniversidad Nacional de Córdoba, Argentina) was used for all the analyses.

\section{RESULTS}

Larvae used different substrates and materials to pupate: wood, sand, cotton or cadaveric tissue. The pupae percentage in the wood was different from the other substrates $(F=20.25$, $d f=2 ; 15, P<0.01)$ and when the type of wood was evaluated the pupae percentage in substrates T2 and T3 was always lower than in T1 under the same larval density conditions, decreasing in this later case when larval density increased $(F=20.25, d f=2 ; 15, P<0.01)$ (Fig. 2).

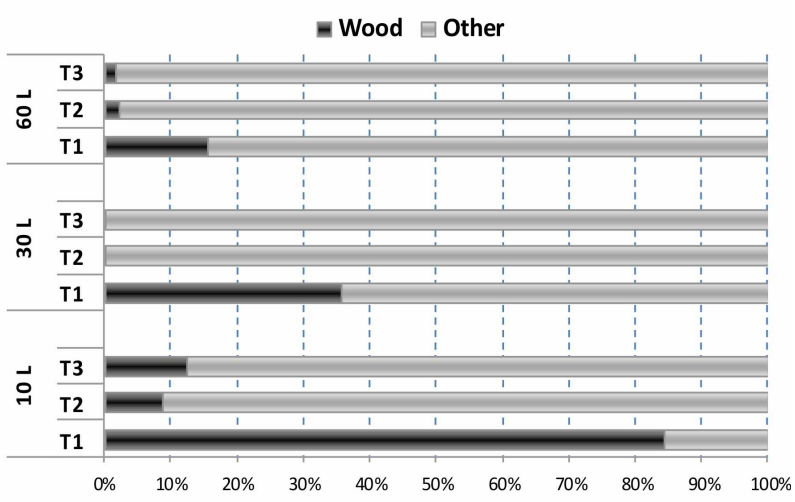

Fig. 2. Dermestes maculatus pupae percentage since substrates types and larval densities. Cotton, cat litter and pork substrates were grouped in the category "Other". T1: soft wood; T2: semi-hard wood; T3: hard wood. $10 \mathrm{~L}$ : 10 larvae; 30 L: 30 larvae; 60 L: 60 larvae 
Larval mortality was greater in the presence of 60 larvae than in the other larval densities $(F=5.73$, df $=2 ; 51, \mathrm{P}<0.01)$ (Fig. 3a). On the other hand, pupal mortality was not affected by larval densities $(F=0.03$, $\mathrm{df}=2 ; 15, \mathrm{P}>0.05)$ (Fig. 3b), thus a total pupal mortality was of $31.6 \%$ was calculated.

The sex ratio was $1.16: 1$ (females $53.6 \%$, males $46.4 \%$ ), the difference between sexes was small and negligible, and larval densities did not affect female percentages $(F=0.84, \mathrm{df}=2 ; 15, \mathrm{P}>0.05)$ (Fig. 3c).

The results about duration indicated that no differences were found in the time until pupation between $\mathrm{T} 1$ and the other alternative substrates $(\mathrm{F}=$ 1.25, $d f=12, P>0.05)($ Fig. 4).

Then, the effects of wood substrates and larval densities were evaluated for the time until pupation. There was no interaction between the type of wood and the larval density $(F=1.72, d f=4 ; 60, P>0.05)$, so these variables were analyzed separately. Differences between the wood substrates were found $(F=14.80$, df $=2 ; 60, \mathrm{P}<0.01)$, a lesser duration in T1 (11.15 \pm 0.31 days) was observed than in the other substrates (Fig. 5a). Related to larval densities, the duration increased when the larval density did $(F=36.45$, df $=2 ; 60, P<$ 0.01 ) (for 60 larvae, $14.72 \pm 0.32$ days) (Fig. 5b). Pupa duration was not different between the wood substrates and between the larval densities ( $F=1.46$, df $=4 ; 60, P$ $>0.05$ ). The average duration of this stage was $7.25 \pm$ 0.28 days $(174 \pm 6.72 h)$.

After this, the effects of wood substrates and larval densities were evaluated for the time until adult. The results found were the same described for the time until pupation, meaning that: there was no interaction between the type of wood and the larval density ( $F$ $=1.24$, df $=4 ; 39, \mathrm{P}>0.05)$, a lesser duration was registered in $\mathrm{T} 1$ (18.26 \pm 0.42 days) than in the other wood substrates $(F=14.65, \mathrm{df}=2 ; 39, \mathrm{P}<0.01)$ (Fig. $5 \mathrm{c}$ ), and an increase in the duration was found when the larval density increased (for 60 larvae $22.45 \pm 0.4$ days) $(F=47.32, d f=2 ; 39, P<0.01)$ (Fig. $5 d)$.

Ultimately, it was observed that for adult length there was not interaction between the wood substrate and the larval density $(F=1.25, \mathrm{df}=4 ; 33, \mathrm{P}>0.05)$. Differences were found between the wood substrates, being the adult length greater in $\mathrm{T} 1(0.8 \pm 0.0088 \mathrm{~cm})$ than in the other substrates $(F=9.95, \mathrm{df}=2 ; 33, \mathrm{P}<0.01)$ ( $F i g .6 a)$. Related to larval densities, the adult length decreased $(0.75 \pm 0.0072 \mathrm{~cm})$ when the larval density increased $(F$ $=8.43, \mathrm{df}=2 ; 33, \mathrm{P}<0.01)$ (Fig. 6b)

\section{DISCUSSION}

In this study, the time until pupate and the time until adult were affected by the type of substrate and larval density. Archer \& Elgar (1998) observed that when latestage larvae are incapable of finding an appropriated pupation site a delay in pupation occur. In our study, larvae pupate earlier when soft wood was available and they also preferred this type of wood. Increased larval
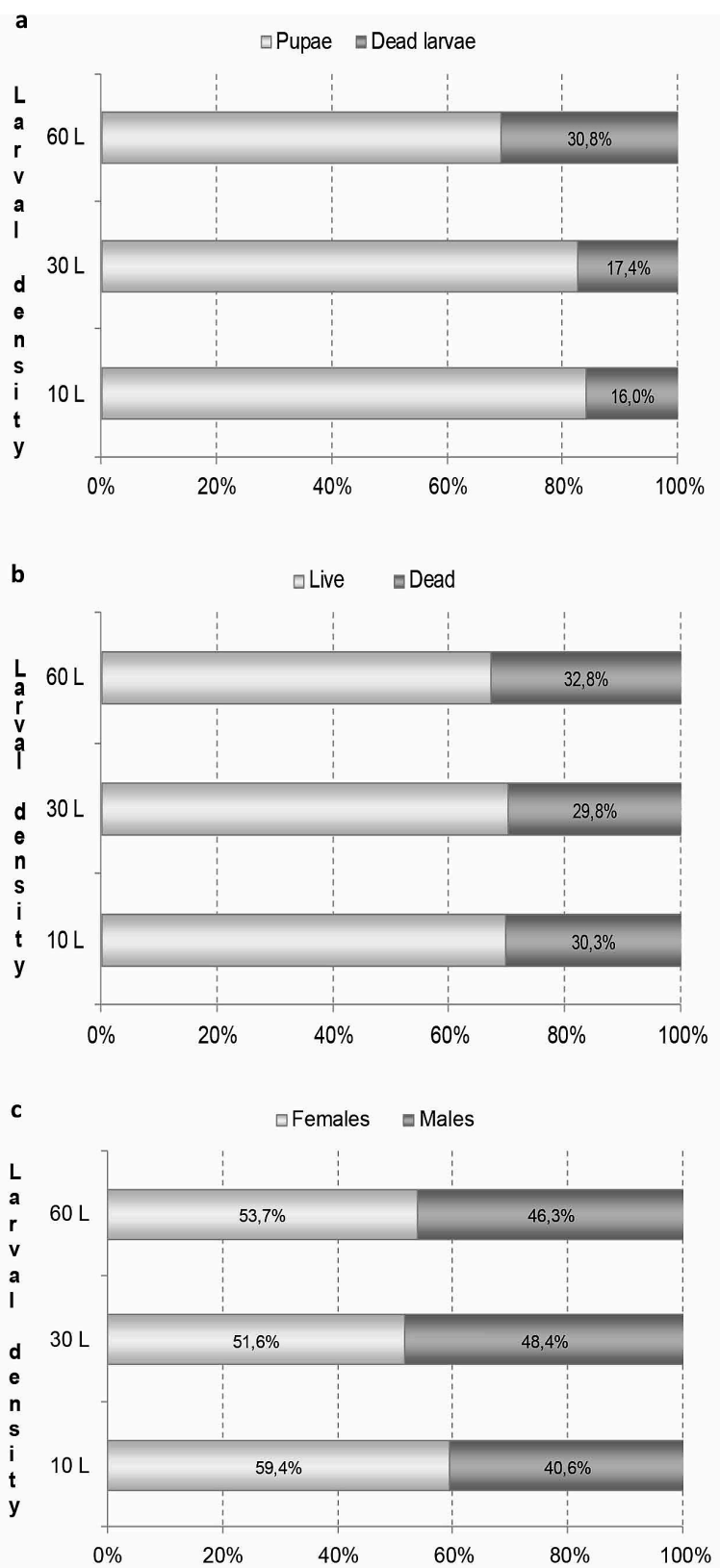

Fig. 3. a. Dermestes maculatus larval mortality and survivorship (\%) since larval densities. b. Hide beetles pupae mortality and survivorship (\%) since larval densities. c. Dermestes maculatus sex ratio or percentages sexes since larval densities. $10 \mathrm{~L}$ : 10 larvae; 30 L: 30 larvae; 60 L: 60 larvae.

density caused opposite effects, maybe because of a reduction in the number of pupation sites. Fontenot et al. (2015) suggested that the amount of refuges is equally or even more important than the type of refuges used, especially when diet is lacking. Indeed, no differences were observed in the time until pupate between the soft wood and the other alternative substrates.

We observed that larval mortality but not pupae 


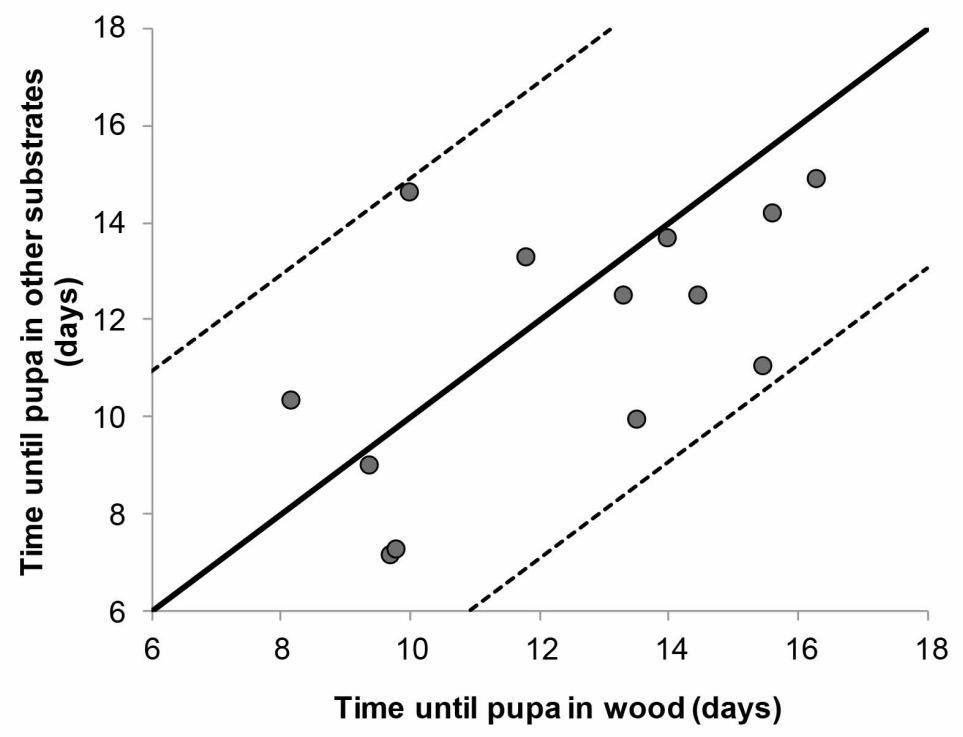

Fig. 4. Time until pupation (days) comparison of hide beetles between $\mathrm{T} 1$ (axis $\mathrm{X}$ ) and other substrates (axis Y). Central line: $\mathrm{X}=\mathrm{Y}$. Pointed lines: \pm 2 standard deviations. Other substrates: cotton, cat litter and pork substrates.
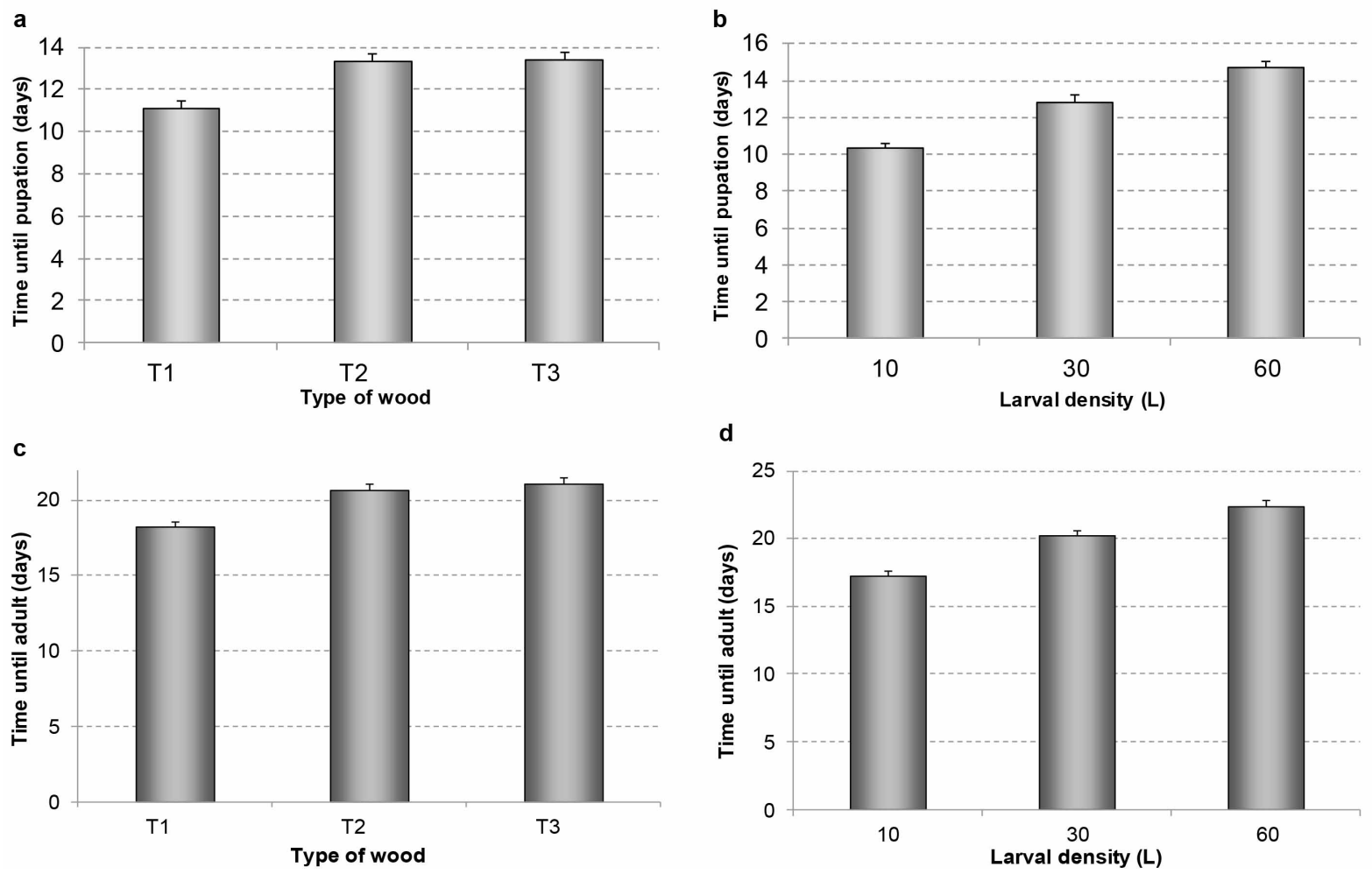

Fig. 5. Dermestes maculatus time until pupation (days) considering treatments: a. Wood type. b. Larval density. Dermestes maculatus time until adult (days) considering treatments: c. Wood type. d. Larval density. T1: soft wood; T2: semi-hard wood; T3: hard wood. 10 L: 10 larvae; 30 L: 30 larvae; 60 L: 60 larvae

mortality was affected by increasing larval density and that mortality was a result of cannibalism and apparently internal processes of prepupae or pupae. These processes for some reasons led larvae or pupae to death. Mortality may happen because the larvae did not find a place to pupate in an appropriate time. Archer \& Elgar (1998) described that the highest rate of mortality in their study was caused by cannibalism of larvae and exposed pupae by other larvae. These authors suggested that cannibalism is triggered by closeness 
to counterparts instead by starvation, which may predispose the insects to cannibalism. In a similar way, Fontenot et al. (2015) described that cannibalism by larvae and adults, especially on the pupae, was common but it could be minimized by providing refuges for larvae to be utilized as pupation sites. At greater larval densities, cork refuges increased survival to the adult stage by nearly $50 \%$ by reducing cannibalization (Fontenot et al., 2015).

Other consequences related to delayed pupation were the negative effects observed on adult beetle health through measuring length and noting vulnerability to an infection which probably was caused by a fungus (Archer \& Elgar, 1998). In our study, smaller adults were evidenced when semi-hard and hard wood were provided and larval density was greater. With these substrates, both the time until pupate and the time until adult were larger, so it could be thought that the adult length was smaller with larger pupation time and with larger adult emergence. Several authors indicated that body size has often been shown to be positively correlated with various aspects of fitness (Peters, 1983; Honek, 1993; Tammaru et al., 2002). Indeed, Bonner (2006) reported that at a greater body size, performance and dominance of organisms or fitness increase. For example, with respect to hide beetles, female fecundity and mate choice have been shown to be positively correlated with body length/size (Archer \& Elgar, 1999; Jones \& Elgar, 2004). Besides, Archer \& Elgar (1998) suggested that a larger body mass probably means vigorous and vital hide beetles able to travel greater distances than smaller individuals, in search of patchy resources. Woodcock et al. (2013) also pointed out that longer survivorship of adults may be related to larger body size facilitating this, the finding of a patchy resource. In fact, Hanski (1987) showed a positive correlation between body size in carrion- and dungfeeding insects with different fitness-related features, including female fertility.

Geden \& Carlson (2001) mentioned that Dermestes larvae form pupal cells into wood and insulation materials, and damage building support posts and joists (Cloud \& Collison, 1985; Stafford et al., 1988). Geden \& Carlson (2001) also proposed using mechanical barriers to prevent beetles' passage as these insects attempt to emigrate from the manure to reach susceptible building components. In this way, these authors demonstrated that using a polyethylene terephthalate plastic barrier can prevent hide beetle larvae from climbing support posts and walls in poultry houses. However, this mechanism required removal of fly spots with water and sponges, especially when they were abundant. Another setback is that care must be taken to avoid damaging the barrier. Indeed, in Geden \& Carlson (2001), the barrier was damaged with manure removal equipment. It has also been taken into account that all the surface keeps covered with the barrier, because it was observed that hide beetles bored in the wood under the post

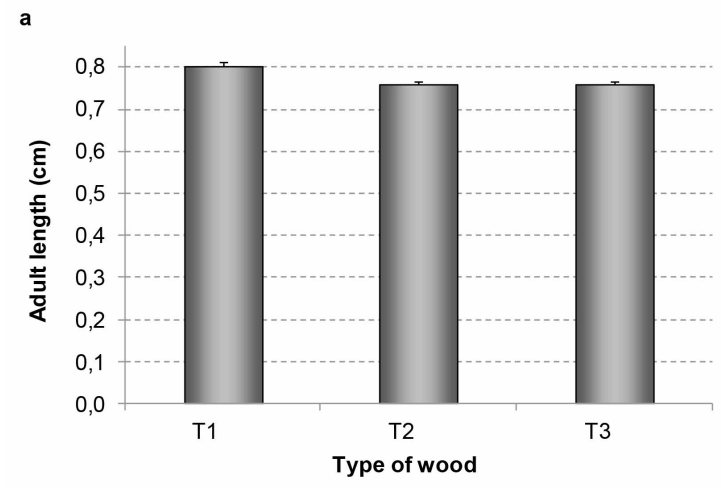

b

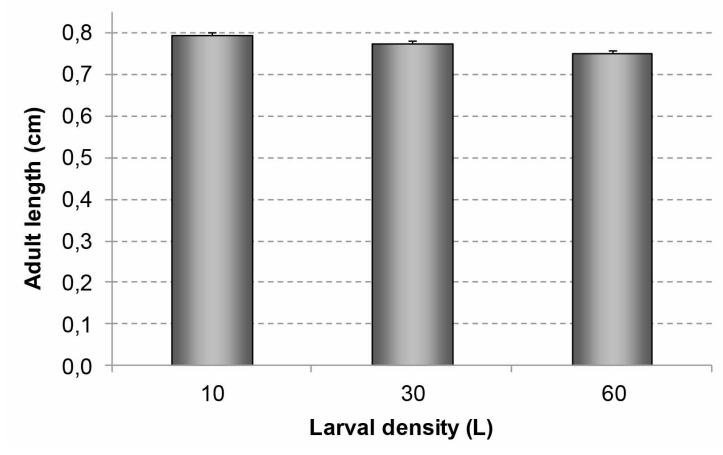

Fig. 6. Dermestes maculatus adult length (cm) considering treatments. a. Wood type. b. Larval density. T1: soft wood; T2: semi-hard wood; T3: hard wood. 10 L: 10 larvae; 30 L: 30 larvae; 60 L: 60 larvae

mounted barriers. In this case, the use of toxicants or repellents was recommended (Ascher, 1993). Still on the subject of insecticides, although the beetles are susceptible to many of them (Cloud \& Collison, 1985; Geden et al., 1987) there are limitations on their effectiveness in the field due to dust and animal waste (in the case of mills and facilities) which accumulate on the treated surfaces (Despins et al., 1991). Based on our study, we recommend another alternative and simple strategy to manage dermestids, the use of semi-hard or especially hard wood to build or reinforce the existing barns or livestock structures. Different accessible woods are available in markets such as $A$. caven as it was used in this study, but other species with the characteristic mentioned above may fulfill the same role and goal. Moreover, this strategy will make buildings or structures durable and avoid all the disadvantages that other techniques have. For scientific purpose, the use of wood will depend on the study aim, but for rearing colonies the use of soft wood is perfect. Likewise, as was indicated above in the discussion section, the results suggested that in forensics, all possible pupating substrates and particularly the floor, the furniture, and other objects of wood, from a scene should be investigated by entomologists in search of post feeding larvae or pupa, being more exhaustive this analysis when soft wood 
ZANETTI, N.I. et al. Effects of wood and larval density on D. maculatus pupation

is available. Furthermore, PMI estimations would be compromised if it is not considered that variations in the time until pupa and until adult could occur depending on the type of wood and/or larval densities.

Finally, this new data may be relevant for pest management as well as for forensic entomology and biological sciences. Soft wood and increasing larval density had effects on hide beetle's pupation, affecting the larvae preference for woods, the larval mortality, the time until pupate, the time until adult, and the adult morphology. The data allow us to make recommendations to farmers and ranchers to build facilities or barns as well as to scientists to perform research. Entomologists should be careful when estimating PMI, especially when wood is a potential pupating substrate.

\section{ACKNOWLEDGEMENTS}

The authors wish to thank Lic. Ricardo Camina for helping with the statistical analysis and to Natalia Difilippo (English public translator) for reviewing the English language. Also, the authors wish to thank Universidad Nacional de Quilmes and Universidad Nacional del Sur, for financially support this work. Noelia I. Zanetti thanks Consejo Nacional de Investigaciones Científicas y Técnicas.

\section{LITERATURE CITED}

Archer, M.S., \& Elgar, M.A. (1998) Cannibalism and delayed pupation in hide beetles, Dermestes maculatus DeGeer (Coleoptera: Dermestidae). Australian Journal of Entomology, 37, 158-161.

Archer, M.S., \& Elgar, M.A. (1999) Female preference for multiple partners: sperm competition in the hide beetle, Dermestes maculatus (DeGeer). Animal Behaviour, 58, 669-675.

Ascher, K.R.S. (1993) Nonconventional insecticidal effects pesticides available from the neem tree, Azadirachta indica. Archives of Insect Biochemistry and Physiology, 22, 433-449.

Bennet, G.W., Owens, J.M., \& Corrigan, R.M. (1988) Truman's Scientific Guide to Pest Control Operations, 4th Edition. Edgell Communication, Minnessota, USA.

Bonner, J.T. (2006) Why size matters. Princeton University Press, Princeton, USA.

Clark, M.A. (1929) Insects Affecting Opossum-skins in New Zealand. New Zealand Journal of Agricultural Research, 39, 260-261.

Cloud, J.A., \& Collison, C.H. (1985) Laboratory evaluation of insecticides for control of adult and larval hide beetles, Dermestes maculatus DeGeer, from poultry houses. Journal of Agricultural Entomology, 2, 297-308.

Cloud, J.A., \& Collison, C.H. (1986) Comparison of various poultry house litter components for hide beetle (Dermestes maculatus DeGeer) larval development in the laboratory. Poultry Science Journal, 65, 1911-1914.
Despins, J.L., Turner Jr., E.C., \& Pfeiffer, D.G. (1991) Evaluation of methods to protect poultry house insulation from infestations by lesser mealworm (Coleoptera: Tenebrionidae). Journal of Agricultural Entomology, 8, 209-217.

Florent, B.O.S., Lucie, A.-T., Judith, G.A., Wango, S.P., Zinga, I., Namkosséréna, S., Lakouèténé Didier, P.-B., Kongueret, E., \& Semballa, S. (2015) The efficient role of Dermestes in damage of fish in Bangui (Central African Republic). Advances in Entomology, 3, 111-117.

Fontenot, E.A., Arthur, F.H., \& Hartzer, K.L. (2015) Effect of diet and refugia on development of Dermestes maculatus DeGeer reared in a laboratory. Journal of Pest Science, 88, 113-119.

Geden, C.J., \& Carlson, D.A. (2001) Mechanical barrier for preventing climbing by lesser mealworm (Coleoptera: Tenebrionidae) and hide beetle (Coleoptera: Dermestidae) larvae in poultry houses. Journal of Economic Entomology, 94, 1610-1616

Geden, C.J., \& Steinkraus, D.C. (2003) Evaluation of three formulations of Beauveria bassiana for control of lesser mealworm and hide beetle in Georgia poultry houses. Journal of Economic Entomology, 96, 1602-1607.

Geden, C.J., Edwards, T.D., Arends, J.J., \& Axtell, R.C. (1987) Efficacies of mixtures of insecticides and disinfectants. Poultry Science Journal, 66, 659-665.

Goff, M.L. (1993) Estimation of postmortem interval using arthropod development and succession patterns. Forensic Science Review, 5, 82-94.

Hanski, I. (1987) Nutritional ecology of dung- and carrionfeeding insects. Nutritional Ecology of Insects, Mites and Spiders (ed. Slansky, F.J.R., \& Rodriguez, J.G.), pp. 837-884. Wiley and Sons, Chichester.

Hefti, E., Trechsel, U., Rüfenacht, H., \& Fleisch, H. (1980) Use of dermestid beetles for cleaning bones. Calcified Tissue International, 31, 45-47.

Hinton, H.E. (1945) A Monograph of the Beetles Associated with Stored Products, Volume I. British Museum (Natural History), London, United Kingdom.

Honek, A. (1993) Intraspecific variation in body size and fecundity in insects: a general relationship. Oikos, 66, 483-492.

Jefferies, M.G. (1979) The occurrence of Dermestes species (Coleoptera: Dermestidae) in "deep pit" poultry houses in Britain. Entomologist's Gazette, 30, 207-212.

Jones, T.M., \& Elgar, M.A. (2004) The role of male age, sperm age and mating history on fecundity and fertilization success in the hide beetle. Proceedings of the Royal Society of London Serie B, 271, 1311-1318.

Kritzinger, C.C. (1955) The control of insect damage to hides and skins. Research Bulletin of Leather Industries Research Institute (Grahamstown, South Africa), 156, 159-167.

Levinson, H.Z., Barelkovsky, J., \& Bar Ilan, A.R. (1967) Nutritional effects of vitamin omission and antivitamin administration on the development and longevity of the hide beetle Dermestes maculatus Deg. (Coleoptera: Dermestidae). Journal of Stored Products Research, 3, 345-352.

Oliva, A. (2001) Insects of forensic significance in Argentina. Forensic Science International, 120, 145-154. 
Mainquist, C., Ellingson, J., Holscher, K., Karriker, L., Hocker, J., \& Blomme, B. (2015) Dermestes maculatus infestation of swine barns. Audubon Manning Veterinary Clinic and Swine Medical Education Center, USA. Available at: https://vetmed.iastate.edu/sites/default/files/VDPAM/ Research/Student_Research/Mainquist\%20AASV\%20poster \%20final.pdf

Mairs, S., Swift, B., \& Rutty, G.N. (2004) Detergent: an alternative approach to traditional bone cleaning methods for forensic practice. American Journal of Forensic Medicine and Pathology, 25, 276-284.

McCullagh, P., \& Nelder, J.A. (1999) Generalized Linear Models, Second Ed. Chapman \& Hall, New York.

Osuji, F.N.C. (1975) Some aspects of the biology of Dermestes maculatus DeGeer (Coleoptera, Dermestidae) in dried fish. Journal of Stored Products Research, 11, 25-31.

Peters, R.H. (1983) The ecological implications of body size. Cambridge University Press, Cambridge, UK.

Rajendran, S., \& Parveen, K.M.H. (2005) Insect infestation in stored animal products. Journal of Stored Products Research, 41, 1-30.

Rustin, M.H.A., \& Munro, D.D. (1984) Popular urticaria caused by Dermestes maculatus DeGeer. Clinical and Experimental Dermatology, 9, 317-321.

Samish, M., Argaman, Q., \& Perelman, D. (1992) The hide beetle, Dermestes maculatus DeGeer (Dermestidae), feeds on live turkeys. Poultry Science Journal, 71, 388-390.

Schroeder, H., Klotzbach, H., Oesterhelweg, L., \& Puschel, K. (2002) Larder beetles (Coleoptera: Dermestidae) as an accelerating factor for decomposition of a human corpse. Forensic Science International, 127, 231-236.

Shuttleworth, S.G., \& Galloway, A.C. (1961) Insecticides for controlling dieldrin resistant Dermestidae (Coleoptera) on skins. Research Bulletin of Leather Industries Research Institute (Grahamstown, South Africa), 262, 1-5.

Stafford, K.C.III., Collison, C.H., Burg, J.G., \& Cloud, J.A. (1988) Distribution and monitoring lesser mealworms, hide beetles, and other fauna in high-rise, caged-layer poultry houses. Journal of Agricultural Entomology, 5, 89-101.
Su, N., \& Scheffrahn, R.H. (1990) Sulfuryl fluoride against four beetle pests of museums (Coleoptera: Dermestidae, Anobiidae). Journal of Economic Entomology, 83, 879-882.

Tammaru, T., Esperk, T., \& Castellanos, I. (2002) No evidence for costs of being large in females of Orgyia spp. (Lepidoptera, Lymantriidae): larger is always better. Oecologia, 133, 430-438.

Turner Jr., E.C. (1986) Structural and litter pests. Poultry Science Journal, 65, 644- 648.

Veer, V., Negi, B.K., \& Rao, K.M. (1996) Dermestid beetle and some other insect pests associated with stored silkworm cocoons in India, including a world list of Dermestid species found attaching this community. Journal of Stored Products Research, 32, 69-89.

Wildey, K.B., \& Wayman, C. (1979) The hide beetle (Dermestes maculatus) as a deep pit pest in poultry houses. A.D.A.S. quarterly review, 34, 187-193.

Woodcock, L., Gennard, D., \& Eady, P. (2013) Egg laying preferences and larval performance in Dermestes maculatus. Entomologia Experimentalis et Applicata,148, 188-195.

Zanetti, N.I., Visciarelli, E.C., \& Centeno, N.D. (2014) Taphonomic marks on pig tissue due to cadaveric coleoptera activity under controlled conditions. Journal of Forensic Sciences, 59, 997-1001.

Zanetti, N.I., Visciarelli, E.C., \& Centeno, N.D. (2015) Associational patterns of scavenger beetles to decomposition stages. Journal of Forensic Sciences, 60, 919-927.

Zanetti, N.I., Visciarelli, E.C., \& Centeno, N.D. (2016) The effect of temperature and laboratory rearing conditions on the development of Dermestes maculatus (Coleoptera: Dermestidae). Journal of Forensic Sciences, 61, 375-381. 